Centre interuniversitaire de recherche

en économie quantitative

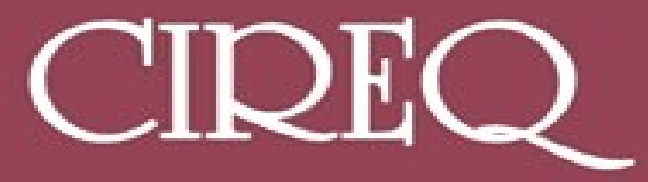

Cahier 05-2004

OPTIMUM TARIFFS AND PATENT LENGTH IN A MODEL OF NORTH-SOUTH TECHNOLOGY TRANSFER

Sharmila VISHWASRAO,

Srabana GUPTA and Hassan BENCHEKROUN 


\title{
CIREQ
}

Le Centre interuniversitaire de recherche en économie quantitative (CIREQ) regroupe des chercheurs dans les domaines de l'économétrie, la théorie économique, la macroéconomie et les marchés financiers, l'économie du travail et l'économie de l'environnement. Ils proviennent principalement des universités de Montréal, McGill et Concordia. Le CIREQ offre un milieu dynamique de recherche en économie quantitative grâce au grand nombre d'activités qu'il organise (séminaires, ateliers, colloques) et de collaborateurs qu'il reçoit chaque année.

The Center for Interuniversity Research in Quantitative Economics (CIREQ) regroups researchers in the fields of econometrics, economic theory, macroeconomics and financial markets, labor economics, and environmental economics. They come mainly from the Université de Montréal, McGill University and Concordia University. CIREQ offers a dynamic environment of research in quantitative economics thanks to the large number of activities that it organizes (seminars, workshops, conferences) and to the visitors it receives every year.

\section{Cahier 05-2004}

OPTIMUM TARIFFS AND PATENT LENGTH IN A MODEL OF NORTH-SOUTH TECHNOLOGY TRANSFER

\author{
Sharmila VISHWASRAO, Srabana GUPTA and \\ Hassan BENCHEKROUN
}

téléphone : (514) 343-6557 télécopieur : (514) 343-5831 cireq@umontreal.ca http://www.cireq.umontreal.ca

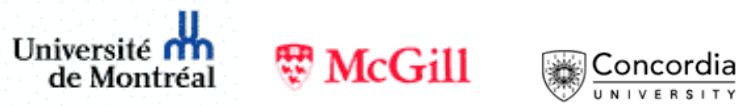


Dépôt légal, Bibliothèque nationale du Canada, 2004, ISSN 0821-4441

Dépôt légal, Bibliothèque nationale du Québec, 2004, ISBN 2-89382-482-X 
Optimum Tariffs and Patent Length in a Model of North-South Technology Transfer Sharmila Vishwasrao*, Srabana Gupta**, and Hassan Benchekroun***

\begin{abstract}
$\underline{\text { Abstract }}$
This paper constructs a theoretical model of trade and technology transfer to study a developing country's choice of optimum tariffs and patent length. A Northern firm has a new good, which it must export to or produce in a Southern country. The Southern government simultaneously chooses an import tariff and patent length to maximize its welfare and induce foreign direct investment (FDI). The absence of patent protection requires high tariffs to induce FDI. This reduces welfare when the good is imported. A combination of patent length and tariffs can be used to reduce this loss and induce FDI. Thus Southern countries may have an incentive to protect patents, although never to the same extent as Northern countries.
\end{abstract}

JEL Classification: O34, F13, F23.

Keywords: Trade Policy, Intellectual Property Rights, Foreign Direct Investment

Acknowledgements: We would like to thank Marie Thursby and numerous seminar participants for their comments.

*Associate Professor, Florida Atlantic University

**Assistant Professor, The Penn State University, Erie

**Assistant Professor, McGill University

Corresponding author: Hassan Benchekroun, Department of Economics, McGill

University, Montreal, QC, Canada H3A-2T7.

Phone: 514-398-2776

Fax: 514-398-4938

Email: hassan.benchekroun@mcgill.ca 


\section{Introduction}

Recent trade negotiations have provided for uniform patent protection among countries while significantly reducing tariffs. The most contentious issue between developed and developing countries in this regard has been the desire of Southern countries to free ride on the research expenditures of Northern firms by providing smaller amounts of patent protection. As is well known, developing countries have little incentive to protect patents because the static welfare losses resulting from higher prices are not offset by dynamic gains from $R \& D$ and new product innovation. However, when the effects of potential technology licensing and FDI are considered, developing countries may gain from technology spillovers if patent protection induces licensing or FDI. This paper makes two contributions to the literature on trade related intellectual property rights (TRIPs). By linking tariff protection to patent length, we provide a direct rationale for the inclusion of intellectual property rights in trade negotiations. We also show that Southern countries may have an incentive to protect foreign patents because of their role in facilitating technology transfer to the South.

The literature on trade related intellectual property has devoted some attention to the Southern countries' incentives to protect patents based on R\&D and technology transfer considerations. Southern countries may have an incentive to protect Northern patents if the resulting research expenditures are very productive or result in innovations that benefit Southern countries. (See Chin and Grossman, 1990, Diwan and Rodrick, 1991 and Deardorff, 1993) Alternatively, a lack of patent protection may lead to reductions in technology transfer or behavior by Northern firms that reduces the benefits of technology transfer to the South, providing an incentive for Southern countries to 
protect patents. (Taylor, 1993, Vishwasrao, 1994, and Zigic, 1998.) Similarly there is a large literature going back to Nordhaus $(1969,1972)$ and Scherer $(1972)$, which analyzes the effects of patent length on welfare. The link between patents and tariffs, however, has received scant attention. In a notable exception Zigic (2000) considers the role of countervailing tariffs in inducing more stringent patent protection by Southern countries. In a model where Southern governments choose the scope of patent protection and Northern governments choose tariffs, Zigic shows that Southern governments may protect patents to prevent the imposition of prohibitive tariffs.

The focus of our paper is not on the notion of punitive tariffs by the North, but rather on the role of patents in the process of trade liberalization. The Southern planner chooses both optimal patent length and the tariff rate to maximize welfare. The source of the linkage between patent length and tariffs in our paper is the ability of both to influence foreign direct investment. The link between FDI and intellectual property rights has been explicitly recognized in studies on the new TRIPs agreement in the WTO. A United Nations study in 1997 acknowledges that, "The integration of intellectual property rights in the international trading system could mean potential short- and long term benefits in terms of prospects for enhanced market access and a more conducive framework for foreign investment and transfer of technology”. The same study also cites evidence from Chile showing a large increase in the number of domestic and foreign applications for patents and trademarks as well as a rapid expansion in inward FDI since acceding to the Paris Convention in $1991^{1}$. Earlier empirical studies also support this

\footnotetext{
${ }^{1}$ Although it is not clear that the increase in FDI can be attributed to the improvement in intellectual property rights alone.
} 
view. Ferrantino (1993) finds that multinationals firms will prefer to locate production where IPRs are well recognized. In addition, Ferrantino also finds a tendency for U.S firms to have higher transfer exports to its affiliates in countries that do not protect IPRs possibly in an attempt to conceal production technology. Lee and Mansfield (1996) using survey data from U.S. multinationals show that differences in intellectual property regimes have a significant impact on the volume and composition of FDI. Lower levels of intellectual property protection tend to reduce the volume of FDI and also the funds invested in R\&D facilities in the host countries. Even in an industry like pharmaceuticals where imitation is relatively easy even without foreign investment, Lanjouw (1998) finds that in the Indian pharmaceutical industry, few multinationals choose to produce their patented drugs in India because, in the words of one executive, there is 'always something to lose', particularly through employee job switching. Glass and Saggi (2002) also assume that technology transfer can occur through post FDI hiring of source firm workers by host country firms.

In our model, tariffs play a dual role. First, when the foreign exporter is a monopolist, as is typically the case when new technology is involved, optimum tariff arguments apply. The tariff can be welfare improving for the importing country since it provides a way of extracting monopoly profits from the foreign producer in the absence of FDI (Katrak, 1977, Brander and Spencer, 1981). The second role played by tariffs is in inducing FDI. Corden (1974) and Svedberg (1979) show that when host country welfare is higher with FDI there is an additional reason to levy a tariff - to induce FDI. This tariff, called the 'switchover tariff' by Svedberg, is typically higher than the tariff 
without FDI. Foreign direct investment is particularly beneficial in our paper because it makes it possible for domestic firms to imitate new technology.

Thus a country may end up with prohibitively high tariffs in an attempt to attract FDI. This has a downside when the good is imported for any length of time. In the product cycle literature (Vernon, 1966), for instance, a new good is typically produced in the innovating country and then production moves to countries with lower production costs when the technology gets older. This poses a problem for the importing country. If the good is imported for any length of time, the switchover tariff reduces welfare relative to the tariff without FDI during that period. The introduction of patent length as a policy variable changes the trade off. Offering a longer patent length allows the country to lower tariffs and still induce FDI.

Our main findings are that the optimum outcome for the Southern country involves a lower tariff and a longer patent length, a result that is consistent with the recommendations of the WTO. The optimum patent length predictably varies with the ability of a country to imitate. Southern countries that find imitation relatively easy are more likely to choose a shorter patent length. Alternatively, goods that are technologically more advanced and thus harder to imitate are better treated with lower tariffs and longer patent length. We also find that cost-reducing improvements in technology may reduce Southern welfare by making it necessary to offer longer patent protection to induce FDI

II. The model 
There are two countries, one in the North and the other in the South. A Northern firm holds a patent on a new good in the North. Assume that the Northern market is supplied through production in the North. We assume that patent length in the North is infinite $^{2}$. The good will be exported from the North to the South until an exogenously determined date $G$, where $G \in[0, \infty]$. In the product cycle literature, the period until $G$ would be analogous to the new product stage. We can also interpret $G$ as varying with the state of technology in a country or how hi-tech the good itself is. Firms from technologically advanced countries may be able to produce newer goods sooner - earlier $G$, or alternatively, the more hi-tech the good, the later the date, before a Southern country can produce it. At date $G$, the Northern firm must decide whether to continue to supply the Southern market through exports or set up a subsidiary in the South (FDI). If the firm chooses to establish a subsidiary, a date, $\mathrm{T}$ at which to set up the subsidiary must also be chosen. The decision to set up a subsidiary is assumed to be irreversible. In the South, patents are protected beginning from the time the Northern firm locates in the South ${ }^{3}$, for a period of time $L$. Imitation takes place after FDI occurs and the period of patent protection in the South, $L$, expires. Once imitation occurs, we assume that the market in the South is perfectly competitive.

\footnotetext{
2 This is a more restrictive assumption than is needed, but simplifies the exposition. The same results are obtained with finite patent length in the North as long as markets in the South become perfectly competitive after patents expire in the South.

${ }^{3}$ The timing of patent length could begin at the same time in the North and South, which would be consistent with the new WTO guidelines. In the paper, we have patent length begin at the same time as FDI. Ultimately this makes no difference to our analysis - we can just add $G_{n}$ to $L$ to get a solution that is consistent with the Paris Convention.
} 
The Southern government moves first to announce a patent length, $L$, and the tariff rate, $\tau$, that applies to imports of the new good. We assume that the tariff rate is applicable for the entire period of the game and is permanent. This allows us to abstract from problems of time inconsistency and committment ${ }^{4}$. (See Miyagiwa and Ohno (1995) and Neary and Leahy (2000) for discussion of temporary vs. permanent tariff protection). The assumption of permanent tariff rates is also consistent with WTO requirements that do not allow countries to raise bound tariffs lines without substantial justification. After the announcement, the Northern firm decides whether and when to locate a subsidiary in the South.

Let $w^{i}$ where $i=\tau$, FDI, and $c$ refer to Southern welfare with imports, FDI and perfect competition respectively. At each moment, welfare is the sum of the consumer and producer surplus, and tariff revenue as appropriate. Note that $w^{\tau}, w^{F D I}$, and $w^{c}$ are maximum welfare levels (and not welfare functions of output) corresponding to the welfare functions evaluated at their respective welfare maximizing quantity of output. $W$ refers to the discounted sum of welfare. Assume that $w^{\tau}$ is a strictly concave function of $\tau$. Similarly let $\pi^{i}$ where $i=\tau$, FDI and c, denote, respectively, the instantaneous profits of the Northern firm from sales in the South from exporting with a tariff, FDI (during the period of patent protection) and competition (once imitation occurs). Let $\Pi^{\tau}$ be the discounted sum of profits with exports only and let $\Pi^{F D I}$ be discounted profits with FDI. We have

\footnotetext{
${ }^{4}$ The assumption can further be justified by WTO rules that prevent countries from easily raising 'bound' tariff rates or changing patent length after signing the TRIPs agreement.
} 


$$
\begin{aligned}
& \Pi^{\tau}=\int_{t=0}^{\infty} \pi^{\tau} e^{-r t} d t \\
& \Pi^{F D I}=\int_{t=0}^{T} \pi^{\tau} e^{-r t} d t+\int_{t=T}^{T+L} \pi^{F D I} e^{-r t} d t+\int_{t=T+L}^{\infty} \pi^{c} e^{-r t} d t
\end{aligned}
$$

Since the Southern market is perfectly competitive once patent protection ends we have $\pi^{c}=0$. Moreover $\pi^{\tau}$ is assumed to be a strictly convex decreasing function of the tariff rate $\tau$ and $\pi^{\tau} \leq \pi^{F D I}$ for any positive $\tau$. Note that all profit functions denote profits for the Northern firm and all welfare functions are for the South.

III. Optimum patent length and tariffs

As benchmarks, we first calculate what the optimum tariff would be in the absence of FDI and what the switchover tariff would be in the absence of patent protection to induce FDI. Without the possibility of FDI, the Southern government will choose a tariff rate to maximize the discounted sum of consumers’ surplus and tariff revenue from exporting the good.

$$
\underset{\tau}{\operatorname{Max}} W=\int_{t=0}^{\infty} w^{\tau} e^{-r t} d t
$$

Evaluating the terms and differentiating with respect to $\tau$ yields the following first order condition

$$
r \frac{\partial W}{\partial \tau}=\frac{\partial w^{\tau}}{\partial \tau}
$$

Setting (4) equal to zero and solving for $\tau$ yields the traditional optimum tariff to extract some monopoly profits from the Northern firm. Let it be denoted by $\tau_{o}$. It can easily be 
seen that the South would prefer to have positive imports to maximize welfare and thus $\left.\pi^{\tau}\right|_{\tau=\tau_{o}}>0$

Now consider the South's problem if it would like to induce FDI but without offering patent protection. To induce FDI, the tariff (called the switchover tariff, $\tau_{s}$ ) must be such that the discounted profits from FDI are at least as great as the profits from exports

$$
\Pi^{\tau} \leq \Pi^{F D I} \text { with } L=0 .
$$

In the absence of patent protection, post-FDI profits are zero. (5) is satisfied when the tariff is set at a prohibitive level such that the quantity of imports is zero and thus profits for the Northern firm from exporting are also zero. Thus the switchover tariff is the same as the prohibitive tariff when patents are not protected. Since profits are decreasing in $\tau$, $\tau_{o}<\tau_{s}$.

Having characterized $\tau_{o}$ and $\tau_{s}$, we can now turn to the optimum combination of patent length and tariffs. Consider the Northern firm's decision of whether and when to locate in the South. Proposition 1 describes the best response of the Northern firm (whether and when to locate a subsidiary in the South) to a given pair of tariff rate and patent length adopted by the Southern government.

Proposition 1: For any given pair of tariff rate and positive patent length $(\tau, L)$ adopted by the Southern government, the Northern firm chooses to locate in the South at date $\mathbf{T}$ such that:

(i) $\mathbf{T}=\mathbf{G}$ for $L>\widetilde{L}$ 
(ii) $\mathbf{T}=\infty$ for $L<\tilde{L}$, where $\tilde{L}=-\frac{1}{r} \ln \left[1-\frac{\pi^{\tau}}{\pi^{F D I}}\right]$

Proof: See Appendix A.

Proposition 1 simply states that for small values of L, the Northern firm would choose to delay FDI indefinitely, but if patent length is long enough, FDI will occur as soon as possible. This is because FDI has two effects on Northern profits. FDI increases Northern profits by avoiding the tariff that the Southern government imposes on imports. But FDI decreases Northern profits since the Southern market becomes perfectly competitive at the end of the protection period. For a given interest rate and tariff rate, if $L>\widetilde{L}$ it is more profitable for the Northern firm to choose FDI sooner rather than later. For $L=\widetilde{L}$ the Northern firm is just indifferent between setting up its subsidiary at $G$ and never setting up a subsidiary. We assume that in this case it would prefer doing FDI at G.

Given this information about the Northern firm’s decision process regarding FDI, we now turn to the decision of the Southern government - the choice of a tariff rate and patent length. The South benefits from FDI because of the possibility of imitation once patent protection ends. The market becomes perfectly competitive ${ }^{5}$ and the instantaneous welfare increases as compared to the import scenario (no matter what the import tariff is). FDI imposes a cost because it results in a loss of tariff revenues without the offsetting gains from competition while patents are protected. These two conflicting effects of FDI in the South make the choice between FDI and imports ambiguous. The South will

\footnotetext{
${ }^{5}$ It is not necessary that the Southern market is perfectly competitive, but rather that welfare in the South is higher after imitation for the results in the paper. Assuming less than perfect competition will affect the patent length but not qualitatively.
} 
generally prefer FDI if the gains in welfare achieved when imitation starts are important enough (in addition to the usual arguments about lower production costs in the South). We restrict our attention to the case where the South prefers FDI to imports.

If the Southern government prefers FDI, it would obviously want FDI to take place with the shortest patent length possible (ideally zero). Zero patent length is not possible, however, because for any tariff rate a minimum patent length is required to ensure FDI by the Northern firm. In addition to a short patent length, the Southern government would prefer FDI as soon as possible, i.e. at G. From Proposition 1, to induce FDI, the tariff rate and the patent length must satisfy $L \geq \widetilde{L}$.

The objective of the Southern government is thus to maximize the discounted sum of instantaneous welfare subject to the participation constraint that the Northern firm would choose FDI at G.

$$
\underset{L, \tau}{\operatorname{Max}} W=\int_{t=0}^{G} w^{\tau} e^{-r t} d t+\int_{t=G}^{G+L} w^{F D I} e^{-r t} d t+\int_{t=G+L}^{\infty} w^{c} e^{-r t} d t
$$

Subject to:

$$
L \geq \tilde{L}=-\frac{1}{r} \ln \left[1-\frac{\pi^{\tau}}{\pi^{F D I}}\right]
$$

Evaluating the integrals in (6) yields:

$$
r W=w^{\tau}\left(1-e^{-r G}\right)-w^{F D I}\left(e^{-r(G+L)}-e^{-r G}\right)+w^{c} e^{-r(G+L)} .
$$

Differentiating (8) with respect to L, we find that:

$$
r \frac{\partial W}{\partial L}=-r e^{-r(G+L)}\left(w^{c}-w^{F D I}\right)<0 .
$$

Thus welfare is clearly reduced by a higher $L$ and we can substitute $L=\tilde{L}$ into the welfare function to get: 


$$
r W=w^{\tau}\left(1-e^{-r G}\right)-\left(w^{c}-w^{F D I}\right) \frac{\pi^{\tau}}{\pi^{F D I}} e^{-r G}+w^{c}\left(e^{-r G}\right)
$$

Differentiating (10) with respect to $\tau$ yields:

$$
r \frac{\partial W}{\partial \tau}=\left(1-e^{-r G}\right) \frac{\partial w^{\tau}}{\partial \tau}-\left[\frac{w^{c}-w^{F D I}}{\pi^{F D I}}\right] e^{-r G} \frac{\partial \pi^{\tau}}{\partial \tau}
$$

Notice that $r \frac{\partial W}{\partial \tau}>0$ for $G \leq \bar{G}$ where

$$
\bar{G}=\frac{1}{r} \ln \left[\frac{w^{c}-w^{F D I}}{\pi^{F D I}}\right]\left[\frac{\left.\frac{\partial \pi^{\tau}}{\partial \tau}\right|_{\tau=\tau_{s}}}{\left.\frac{\partial w^{\tau}}{\partial \tau}\right|_{\tau=\tau_{s}}}\right]
$$

Thus for $G \leq \operatorname{Max}\{0, \bar{G}\}$ we obtain a corner solution where the tariff chosen is the prohibitive tariff $\tau_{s}$ and the patent length is zero.

For $G>\operatorname{Max}\{0, \bar{G}\}$, setting (11) equal to zero would yield the first order condition for the welfare maximizing tariff and an interior solution for the optimum $\operatorname{tariff} \tau *$. The optimum patent length is chosen to satisfy the participation constraint of the North (7) with equality and

$$
L^{*}=\tilde{L}=-\frac{1}{r} \ln \left[1-\frac{\pi^{\tau}}{\pi^{F D I}}\right]
$$

The second order condition, $\frac{\partial^{2} W}{\partial \tau^{2}}<0$, is satisfied by the assumption of a

Southern welfare function that is concave with respect to tariffs and Northern profits that are convex with respect to tariffs. 
Proposition 2 characterizes the optimum tariff and patent length combination.

Proposition 2: For $G>\bar{G}$, the optimum tariff, $\tau^{*}$, is such that $\tau_{o}<\tau^{*}<\tau_{s}$ and the optimum patent length, $L^{*}=\tilde{L}$ is positive. For $\quad<^{-}, \tau^{*}=\tau_{s}$ and $L^{*}=0$.

\section{(Proof in Appendix B)}

The possibility of imitation makes FDI desirable for the South. Thus the Southern government has an incentive to impose a tariff that will induce FDI - the switch-over tariff. In the absence of patent protection, this tariff must be close to prohibitive to induce FDI. The switchover tariff is clearly higher than the standard optimal tariff. Consequently, for the time period in which the good is being imported G, the welfare in the South will be reduced by this higher tariff. The South can decrease this welfare loss of deviating from the traditional optimum tariff during the import period because it has two policy instruments to induce FDI - higher tariffs and longer patent length. By charging a lower tariff and offering a longer length of patent protection, the Southern government can reduce the welfare loss of deviating from the optimum tariff in the export period because the patent length does not actually matter in this period. Thus when the switchover tariff is higher than the optimum tariff, the optimum solution for the South involves some positive patent length, combined with a tariff that is lower than the switchover tariff. The loss in welfare due to a longer patent length is less than the welfare gain resulting from the lower tariff, which induces the South to use both tariffs and patent length. Increasing patent length beyond $\mathrm{L}^{*}$ induces a loss in welfare that is 
larger than the welfare gain from a lower tariff. So the optimum patent length is less than provided in the North, but is positive nonetheless ${ }^{6}$.

As $\mathrm{G}$ becomes smaller, the tradeoff changes. Consider, for example, the limiting case where $G=0$. The South can induce FDI through as high a tariff as needed because it is never paid. Since welfare is lowered by protecting patents but is unaffected by tariffs, the corner solution where patent length is zero and the tariff equals the switchover tariff is optimal.

The equilibrium outcome is summarized in Figure 1. Southern welfare increases towards the origin and FDI occurs to the right of $L=\tilde{L}$ line. This implies that the welfare maximizing tariff and patent length is where the iso-welfare curve for the South is tangent to the constraint that FDI occurs.

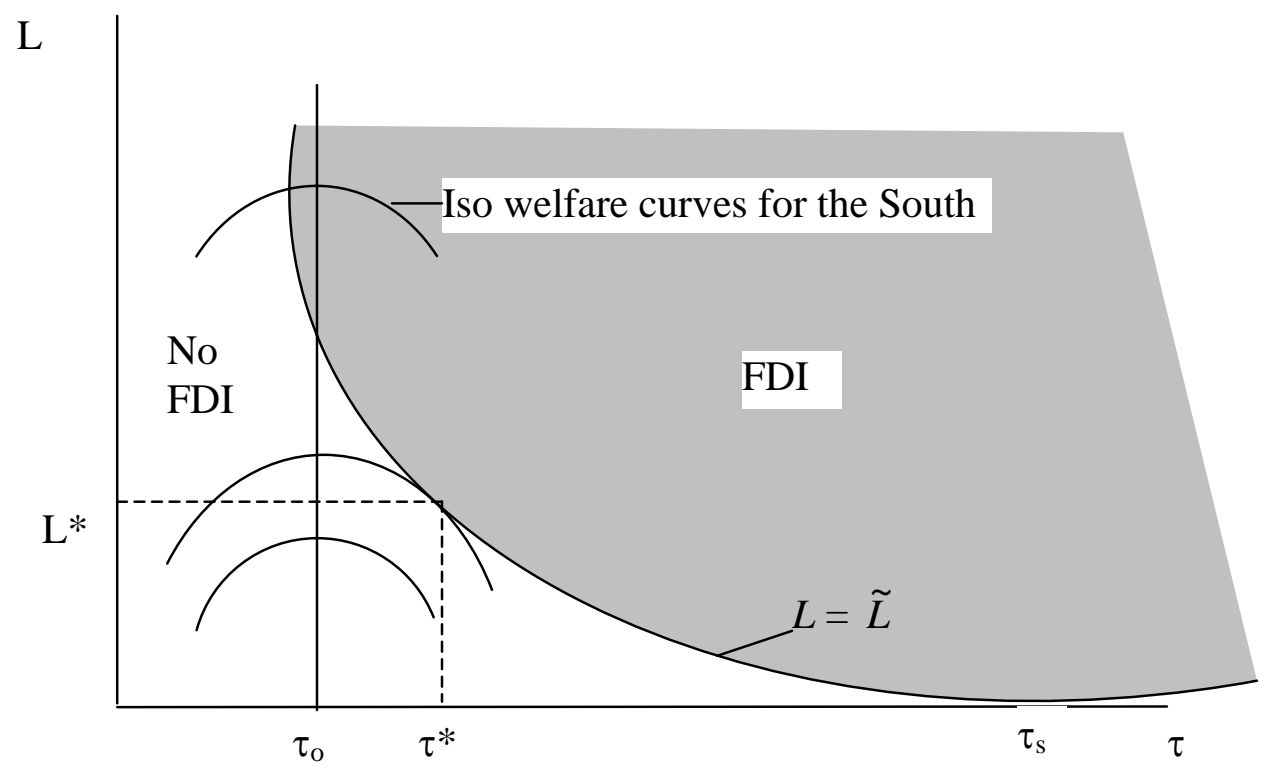

Figure 1: Welfare maximizing tariffs and patent length.

\footnotetext{
${ }^{6}$ In the case of linear demand (see example in section IV), $\bar{G}=-\infty$ so that $\tau_{o}<\tau^{*}<\tau_{s} \forall G \in(0, \infty)$.
} 
Proposition 3: An increase in $\mathrm{G}$ will decrease the level of tariff protection and increase the length of patent protection.

\section{Proof: See Appendix C.}

The optimum tariff lies somewhere between the traditional optimum tariff for a monopolist and the switchover tariff. As G, the date until which the good is exported, is later, the importance of the traditional tariff increases. The Southern government's response is to lower the tariff closer to $\tau_{o}$ and use the patent length to attract FDI instead. This suggests that Southern countries that are more developed and perhaps find it easier to imitate Northern goods (earlier G) might choose shorter patent length and higher tariffs. Counteracting this effect however, if more developed Southern countries import predominantly higher tech goods (higher G) then they might choose lower tariffs and longer patent length.

The welfare of the Southern country depends on several exogenous parameters affecting the optimal combination of the patent length and the tariff. In the following proposition we analyze the effect on welfare of technology improvements that reduce

production costs. For simplicity, we assume that for each level of production, costs in the North and in the South are reduced by the same amount. The cost reduction is however allowed to vary with the level of production. Interestingly, the mechanism of patent length can prove to be a source of welfare loss for the Southern country.

\section{Proposition 4: A change in technology that reduces production costs can reduce} welfare in the South.

Proof: See Appendix D. 
A decrease in costs will unambiguously improve Southern welfare during the post-patent period. However, the change in production costs also affects the decision of the Northern firm to do FDI as well as the timing of FDI. The Northern firm's profits from exports and FDI both increase with a technology improvement. If the former increase outweighs the later, the Northern firm may not choose FDI. The Southern government must offer longer patent length to induce FDI at G, which decreases the benefits of FDI. To sum-up, the effects of a technological improvement in the production process and a reduction in production costs are twofold. First, a lower production cost results in more production and therefore in an increase in welfare. Second, a lower production cost can force the South to offer a longer patent length to induce FDI, which results in a loss in welfare. There exist cost reductions for which the effect of longer patent length on Southern welfare outweighs the effect of a cost reduction.

This is most easily seen in the case of a reduction in fixed costs. The cost reduction increases Northern profits from both FDI and exports equally. Since $\Pi^{F D I}>\Pi^{\tau}$, the ratio of $\frac{\pi^{\tau}}{\pi^{F D I}}$ increases because of the reduction in fixed costs. This changes the participation constraint of the North so that the South must offer a longer patent length to induce the Northern firm to invest as can be seen from the expression for

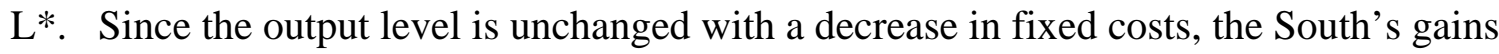
from the cost reduction are limited to the profit increases of imitating Southern firms. In Appendix D we show that these gains are smaller than the welfare losses because of the increased patent length. 


\section{Conclusion.}

Patent protection has been treated as a trade related issue without directly exploring the relationship between tariffs and patent length. This paper attempts to explore the link between patent length and tariff rates through the mechanism of foreign direct investment. High tariffs have often been used as incentives for multinationals to locate in developing countries. While this is successful in attracting FDI it imposes a cost during the time the country imports the good. These losses can be minimized with a combination of tariffs and positive patent length. When a planner can choose both patent length and tariffs simultaneously, we show that the tariff will be lower than if patents were not protected and patent length will be positive but finite. While Southern countries may not pick the same patent length as Northern countries, there is an incentive to protect patents even for countries that conduct no R\&D. Our results provide support for WTO initiatives that seek to reduce tariffs while increasing patent length.

The incentives to protect patents are linked with a country’s ability to imitate or alternatively to the amount of hi-tech goods it imports. Countries that are able to imitate foreign technologies quickly will have little incentive to protect patents for a long time. This suggests that within the group of Southern countries, more developed countries would protect patents for a shorter duration. We can also envision an alternative scenario where more developed countries are likely to import more hi - tech or hard to imitate goods, which are optimally protected with lower tariffs and longer patent length.

We also find that when a foreign firm makes technological improvements, increased patent length may be required to induce FDI, possibly reducing welfare in the 
South. Thus patent length is a mixed blessing in our paper. While longer patent lengths allow host countries to reduce the losses from sub-optimal tariffs, they are still a way for foreign firms to earn monopoly rents. This result suggests that given a choice between newer or older technologies Southern countries may be better off importing goods made with older technology since they can acquire these with shorter patent length.

Some extensions of our model include allowing the breadth of patent protection to vary in addition to length, and examining the issue of cost reducing process innovations which would allow us to explore issues of whether it might be optimal for Southern countries to in fact choose older technologies and offer a shorter duration of patent protection. 
References

Brander, James A., and Spencer, Barbara J., (1981) “Tariffs and the Extraction of Foreign Monopoly Rents under Potential Entry.” Canadian Journal Of Economics, Vol. 14, No. 3, August, pp. 371-89.

Chin, Judith C.; Grossman, Gene M., (1990) "Intellectual Property Rights and NorthSouth Trade," in Jones, Ronald W.; Krueger, Anne O., eds.. The Political Economy of International Trade: Essays in honor of Robert E. Baldwin. Oxford and Cambridge, Mass.: Blackwell, pp. 90-107.

Corden, W.M. (1974), Trade Policy and Economic Welfare, Oxford University Press, London.

Deardorff, Alan V (1993), "Should Patent Protection be Extended to all Developing Countries," in Stern, Robert M., ed.. The Multilateral Trading System: Analysis and Options for Change...Studies in International Trade Policy. Ann Arbor: University of Michigan Press, pp 435-48.

Diwan, Ishac, and Rodrik, Dani, "Patents, Appropriate Technology, and North-South Trade," Journal of International Economics, 30(1-2) February 1991, 27-47.

Ethier, Wilfred J. and Markusen, James R. (1996), “Multinational Firms, Technology Diffusion and Trade,” Journal of International Economics, Vol. 41, No. 1-2, August, 128.

Ferrantino, Michael J. (1993), “The Effect of Intellectual Property Rights on International Trade and Investment,” Weltwirtschaftliches Archiv, Vol. 129, 300 - 331.

Glass, Amy Jocelyn and Saggi, Kamal (2002), "Multinational Firms and Technology Transfer,” Scandinavian Journal of Economics, 104(4), 495-513.

Katrak, H. (1977), "Multi-National Monopolies and Commercial Policy,” Oxford Economic Papers, Vol. 29, No. 2, July, 283-91.

Lanjouw, Jean O. (1998), The Introduction of Pharmaceutical Product Patents in India: "Heartless Exploitation of the Poor and Suffering?", NBER Working Paper 6366.

Lee Jeong-Yeon and Mansfield, Edwin (1996), "Intellectual Property Protection and U.S. Foreign Direct Investment”, The Review of Economics and Statistics, Vol. 78, No. 2, May, 181-186.

Miyagiwa, Kaz_and Ohno, Yuka (1995), “Closing the Technology Gap under Protection,” American Economic Review, Vol. 85, No. 4, September, 755-70. 
Neary, J.P and Leahy, D., (2000), "Strategic Trade and Industrial Policy Towards Dynamic Oligopolies,” The Economic Journal, vol. 110, No. 463, pp. 484-508.

Nordhaus, W.D., (1969), Invention, Growth and Welfare; A theoretical treatment of Technological Change, Cambridge, Mass.

Nordhaus, W.D., (1972), “The Optimum Life of a Patent: Reply,” The American Economic Review, Vol. 62, No. 3. (Jun., 1972), pp. 428-431.

F. M. Scherer, (1972) "Nordhaus' Theory of Optimal Patent Life: A Geometric Reinterpretation,” The American Economic Review, Vol. 62, No. 3., pp. 422-427.

Svedberg, Peter, (1979), “ Optimal Tariff Policy on Imports from Multinationals,” Economic Record, Vol.55, No. 148 March, pp. 64-67.

Taylor, M. Scott, (1993) "TRIPS, Trade, and Technology Transfer," Canadian Journal of Economics, Vol.26, No. 3, pp. 625-37.

United Nations (1997), The TRIPs Agreement and Developing Countries, United Nations Conference on Trade and Development, New York.

Vernon, Raymond, (1966) "International Investment and International Trade in the Product Cycle,” Quarterly Journal of Economics, Vol. 80, May, pp. 190-207.

Vishwasrao, Sharmila (1994), "Intellectual Property Rights and the Mode of Technology Transfer," Journal of Development Economics, Vol. 44, No. 2, pp. 381-402.

Zigic, Kresimir (1998), “Intellectual Property Rights Violations and spillovers in NorthSouth Trade,” European Economic Review, Vol. 42, 1779-1799.

Zigic, Kresimir (2000), "Strategic Trade Policy, Intellectual Property Rights Protection, and North South Trade,” Journal of Development Economics, Vol. 61, 27-60. 


\section{Appendix A}

Proof of Proposition 1

The objective of the Northern firm is to choose whether and when (date T) to do FDI in the South, given a pair of tariff rate and patent length announced by the Southern government.

The overall profits of not doing FDI are given by:

$$
\Pi^{\tau}=\int_{t=0}^{\infty} \pi^{\tau} e^{-r t} d t=\pi^{\tau} / r
$$

The objective of the Northern firm is $\operatorname{Max} \Pi^{F D I}=\int_{t=0}^{T} \pi^{\tau} e^{-r t} d t+\int_{t=T}^{T+L} \pi^{F D I} e^{-r t} d t$ with

$$
T \in(G, \infty) .
$$

$$
\begin{aligned}
& \frac{d \Pi^{F D I}}{d T}=\pi^{\tau} e^{-r T}+\pi^{F D I}\left(e^{-r(T+L)}-e^{-r T}\right) \text { or } \\
& \frac{d \Pi^{F D I}}{d T}=e^{-r T}\left(\pi^{\tau}+\pi^{F D I}\left(e^{-r L}-1\right)\right)
\end{aligned}
$$

Therefore

(i) if the tariff rate and the patent length are such $\pi^{\tau}+\pi^{F D I}\left(e^{-r L}-1\right)<0$ the firm chooses to do FDI at G.

(ii) if $\pi^{\tau}+\pi^{F D I}\left(e^{-r L}-1\right)>0$ then $\Pi^{\tau}=\pi^{\tau} / r>\Pi^{F D I}$ for any $T \in(G, \infty)$.

The condition $\pi^{\tau}+\pi^{F D I}\left(e^{-r L}-1\right)>0$ is equivalent to $e^{-r L}>1-\pi^{\tau} / \pi^{F D I}$ or $L<-\frac{1}{r} \ln \left[1-\frac{\pi^{\tau}}{\pi^{F D I}}\right]$. 
Appendix B:

Proof of Proposition 2

We can show that for $G>\operatorname{Max}\{0, \bar{G}\}, \tau_{o}<\tau^{*}<\tau_{s}$ and for $G \leq \operatorname{Max}\{0, \bar{G}\}$, $\tau^{*}=\tau_{s}$. The first term on the RHS of (11) describes the traditional optimum tariff without FDI (same as in (4)). Since $\frac{\partial \pi^{\tau}}{\partial \tau}<0$, the second term is negative, which implies that the optimum tariff here is greater than the traditional optimum tariff without FDI. Alternatively $\left.r \frac{\partial W}{\partial \tau}\right|_{\tau=\tau_{o}}>0$ for all $G \in[0, \infty]$.

At $G=\bar{G},\left.\frac{\partial W}{\partial \tau}\right|_{\tau=\tau_{o}}=0$. Since

$\left.\frac{\partial^{2} W}{\partial \tau \partial G}\right|_{\tau=\tau_{o}}=e^{-r G}\left(\left.\frac{\partial w^{\tau}}{\partial \tau}\right|_{\tau=\tau_{s}}+\left.\left[\frac{w^{c}-w^{F D I}}{\pi^{F D I}}\right] \frac{\partial \pi^{\tau}}{\partial \tau}\right|_{\tau=\tau_{s}}\right)<0$

then $\left.r \frac{\partial W}{\partial \tau}\right|_{\tau=\tau_{s}}<0$ for $G>\bar{G}$.

To summarize, for $G>\bar{G}$ we have $\left.\frac{\partial W}{\partial \tau}\right|_{\tau=\tau_{o}}>0$ and $\left.\frac{\partial W}{\partial \tau}\right|_{\tau=\tau_{s}}<0$. Since $\frac{\partial^{2} W}{\partial \tau^{2}}<0$, there exists a unique $\tau *$ where $\frac{\partial W}{\partial \tau}=0$ such that $\tau_{o}<\tau^{*}<\tau_{s}$.

For $G<\bar{G}$ and $\bar{G}>0,\left.\frac{\partial W}{\partial \tau}\right|_{\tau=\tau_{s}}>0$ and $\left.\frac{\partial W}{\partial \tau}\right|_{\tau=\tau_{o}}>0$, thus there is a corner solution with $\tau^{*}=\tau_{s}$. For any given tariff rate the Southern government clearly has no incentive to announce a longer patent length than the minimum required by Proposition 1 . Therefore for any tariff rate there is a unique corresponding patent length given by $L^{*}=\widetilde{L}=-\frac{1}{r} \log \left[1-\frac{\pi^{\tau}}{\pi^{F D I}}\right]$.

For $G \leq \bar{G}, \tau^{*}=\tau_{\mathrm{s}} \Rightarrow \pi_{n}^{e}=0$ and thus $L^{*}=0$.

Note that if $\bar{G}<0$ we have $G>\bar{G}$ and thus we always obtain the interior solution. 


\section{Appendix C}

Proof of Proposition 3

We need to show that $\frac{\partial \tau^{*}}{\partial G} \leq 0$ and $\frac{\partial L^{*}}{\partial G} \geq 0$.

$\tau^{*}$ is given by the solution to equation (11). Totally differentiating (11) with respect to $G$ we have

$r e^{-r G} \frac{\partial w^{\tau}}{\partial \tau}+\frac{w^{c}-w^{F D I}}{\pi^{F D I}} r e^{-r G} \frac{\partial \pi^{\tau}}{\partial \tau}+\left(1-e^{-r G}\right) \frac{\partial^{2} w^{\tau}}{\partial \tau^{2}} \frac{d \tau^{*}}{d G}-\left(\frac{w^{c}-w^{F D I}}{\pi^{F D I}}\right) e^{-r G} \frac{\partial^{2} \pi^{\tau}}{\partial \tau^{2}} \frac{d \tau^{*}}{d G}=0$

which yields

$$
\frac{d \tau^{*}}{d G}=-\frac{r e^{-r G} \frac{\partial w^{\tau}}{\partial \tau}+\frac{w^{c}-w^{F D I}}{\pi^{F D I}} r e^{-r G} \frac{\partial \pi^{\tau}}{\partial \tau}}{\left(1-e^{-r G}\right) \frac{\partial^{2} w^{\tau}}{\partial \tau^{2}}-\left(\frac{w^{c}-w^{F D I}}{\pi^{F D I}}\right) e^{-r G} \frac{\partial^{2} \pi^{\tau}}{\partial \tau^{2}}}
$$

where all the derivatives are evaluated at $\tau=\tau^{*}$.

From (11) we have

$$
r e^{-r G} \frac{\partial w^{\tau}}{\partial \tau}+\left[\frac{w^{c}-w^{F D I}}{\pi^{F D I}}\right] r e^{-r G} \frac{\partial \pi^{\tau}}{\partial \tau}=r \frac{\partial w^{\tau}}{\partial \tau}
$$

and thus

$$
\frac{d \tau^{*}}{d G}=-\frac{r \frac{\partial w^{\tau}}{\partial \tau}}{\left(1-e^{-r G}\right) \frac{\partial^{2} w^{\tau}}{\partial \tau^{2}}-\left(\frac{w^{c}-w^{F D I}}{\pi^{F D I}}\right) e^{-r G} \frac{\partial^{2} \pi^{\tau}}{\partial \tau^{2}}}
$$

From the concavity of $w^{\tau}$ and the convexity of $\pi^{\tau}$ we can conclude that the denominator of the expression above is negative. Moreover, since $\tau^{*} \geq \tau$ we have $\frac{\partial w^{\tau}}{\partial \tau} \leq 0$ at $\tau^{*}=\tau$. Therefore $\frac{d \tau^{*}}{d G} \leq 0$ with strict inequality for $\tau^{*}>\tau$. From (13) we have

$$
\frac{d L^{*}}{d G}=\frac{\partial L^{*}}{\partial \tau} \cdot \frac{d \tau^{*}}{d G}=-\frac{1}{r}\left(-\frac{1}{\pi^{F D I}} \cdot \frac{\partial \pi^{\tau}}{\partial \tau}\right) \cdot \frac{1}{1-\frac{\pi^{\tau}}{\pi^{F D I}}} \cdot \frac{d \tau^{*}}{d G}
$$

Or $\frac{d L^{*}}{d G}=\frac{1}{r} \cdot \frac{\partial \pi^{\tau}}{\partial \tau} \cdot \frac{1}{\pi^{F D I}-\pi^{\tau}} \cdot \frac{d \tau^{*}}{d G}$

Since $\pi^{\tau}$ is a decreasing function of tariff and since $\frac{d \tau^{*}}{d G} \leq 0$ we have $\frac{d L^{*}}{d G} \geq 0$ with strict inequality for $\tau^{*}>\tau$. 


\section{Appendix D}

Proof of Proposition 4

Let $\gamma A(Q)$ denote the cost reduction resulting from technological improvements. The production costs decrease by the amount $\gamma A(Q)$ where $\mathrm{Q}$ is the quantity produced. The parameter $\gamma$ captures the scale of technology improvements whereas the function $A(Q)$ describes a change in the cost reduction with respect to output. We show through an example that such a technology improvement and decrease in production costs can lower Southern welfare, i.e. $\frac{d W}{d \gamma}<0$. The derivative of (10) with respect to $\gamma$ is given by

$r \frac{d W}{d \gamma}=\frac{d w^{\tau}}{d \gamma}\left(1-e^{-r G}\right)-\frac{d}{d \gamma}\left[\left(w^{c}-w^{F D I}\right) \frac{\pi^{\tau}}{\pi^{F D I}}\right] e^{-r G}+e^{-r G} \frac{d w^{c}}{d \gamma}$

where $w^{c}, w^{F D I}$, and $w^{\tau}$ are given by

$$
\begin{aligned}
& w^{\tau}=\int_{0}^{Q^{\tau}} P(Q) d Q-P\left(Q^{\tau}\right) Q^{\tau}+\tau Q^{\tau} \\
& w^{F D I}=w^{\tau=0}
\end{aligned}
$$

and

$$
w^{c}=\int_{0}^{Q^{c}} P(Q) d Q-c\left(Q^{c}\right)+\gamma A(Q)
$$

$P(Q)$ and $C(Q)$ denote respectively the negatively sloped convex inverse demand function and the cost function (assumed concave). Differentiating $w^{c}, w^{F D I}$, and $w^{\tau}$ wrt $\gamma$, and simplifying yields:

$$
\begin{aligned}
& \frac{d w^{\tau}}{d \gamma}=\left(-P^{\prime}\left(Q^{\tau}\right) Q^{\tau}+\tau\right) \frac{d Q^{\tau}}{d \gamma} \\
& \frac{d w^{F D I}}{d \gamma}=\left(-P^{\prime}\left(Q^{F D I}\right) Q^{F D I}\right) \frac{d Q^{F D I}}{d \gamma}
\end{aligned}
$$

and

$$
\frac{d w^{c}}{d \gamma}=A\left(Q^{c}\right)
$$

A cost reduction lowers Southern welfare if and only if $\frac{d W}{d \gamma}<0$. We show below that this condition is unambiguously satisfied in the case of a decrease in fixed costs $(A(Q) \equiv 1)$. In this case, the output level is unchanged and thus

$$
\frac{d w^{\tau}}{d \gamma}=\frac{d w^{F D I}}{d \gamma}=0
$$

and 


$$
\frac{d w^{c}}{d \gamma}=\frac{d \pi^{\tau}}{d \gamma}=\frac{d \pi^{F D I}}{d \gamma}=1
$$

Substituting the expressions in (D2) and (D3) into (D1) yields

$$
r \frac{d W}{d \gamma}=-\frac{d}{d \gamma}\left[\left(w^{c}-w^{F D I}\right) \frac{\pi^{\tau}}{\pi^{F D I}}\right] e^{-r G}+e^{-r G}
$$

or,

$$
r \frac{d W}{d \gamma}=\left(\left(1-\frac{\pi^{\tau}}{\pi^{F D I}}\right) \frac{\pi^{F D I}-\left(w^{c}-w^{F D I}\right)}{\pi^{F D I}}\right) e^{-r G}
$$

We thus have

$$
\frac{d W}{d \gamma}<0 \text { if }\left[\pi^{F D I}-\left(w^{c}-w^{F D I}\right)\right]<0 .
$$

Since $\left(\pi^{F D I}+w^{F D I}\right)$ is equivalent to Southern surplus under monopoly and since surplus with perfect competition $\left(w^{c}\right)$ is unambiguously larger than the surplus with monopoly, we can conclude that $\frac{d W}{d \gamma}<0$ : any technology improvement that lowers fixed costs will lower Southern welfare. 